\title{
Interactive comment on "Review of the global models used within the Chemistry-Climate Model Initiative (CCMI)" by Olaf Morgenstern et al.
}

\section{Anonymous Referee \#2}

Received and published: 12 November 2016

The comment was uploaded in the form of a supplement:

http://www.geosci-model-dev-discuss.net/gmd-2016-199/gmd-2016-199-RC2-

supplement.pdf

Interactive comment on Geosci. Model Dev. Discuss., doi:10.5194/gmd-2016-199, 2016. 